\title{
RETROSPECTIVE COMPARATIVE ANALYSIS OF SURGICAL TREATMENT OF THORACOLUMBAR BURST FRACTURE: SHORT VERSUS LONG FIXATION
}

\author{
ANÁLISE RETROSPECTIVA COMPARATIVA DO TRATAMENTO CIRÚRGICO DA FRATURA \\ TORACOLOMBAR DO TIPO EXPLOSÃO: FIXAÇÃO CURTA VERSUS LONGA
}

\section{ANÁLISIS RETROSPECTIVO COMPARATIVO DEL TRATAMIENTO QUIRÚRGICO DE FRACTURA TORACOLUMBAR POR EXPLOSION: FIJACIÓN CORTA VERSUS LARGA}

Carlos Alberto de Almeida de Assunção Filho', Nelson Astur Neto', João Paulo Bergamaschi', luciano Antonio Nassar Pellegrino', Ricardo Shigueaki ${ }^{1}$, Galhego Umeta ${ }^{1}$, Maria Fernanda Silber Caffaro' ${ }^{1}$, Osmar Avanzi ${ }^{1}$, Robert Meves ${ }^{1}$

1. Faculdade de Ciências Médicas da Santa Casa de São Paulo (FCMSCSP), São Paulo, SP, Brazil.

\begin{abstract}
Objective: The objective of this study is to compare short posterior fixation to long posterior fixation in thoracolumbar burst fractures. Methods: Fifty-three patients were divided into Group I $(n=24)$ treated with short instrumentation (one level above and one below the fracture) and into Group II ( $n=29)$ treated with long instrumentation (two or more levels above and below the fracture). The load sharing classification was used to stratify cases. The evaluation of the sagittal index was performed using the Cobb method. Results: In subgroups with load sharing classification $\leq 6$, Group I had loss of correction of 4.2 degrees and a procedure failure in 14.3\% of cases, Group II showed loss of correction of 5.4 degrees and failure in $21.7 \%$ of cases. In subgroups with load sharing classification $\geq 7$, Group I had a loss of correction of 11.2 degrees and procedure failure in $70 \%$ of cases, and Group II showed a loss of correction of 9 degrees and failure of $46.7 \%$. Group I had a tendency to worse outcomes, especially in the subgroup of patients with load sharing classification $\geq 7$. Conclusion: Despite the tendency for poorer results in the short fixation group in the cases with load sharing $\geq 7$, in no sample was there statistically significant difference between the groups studied.
\end{abstract}

Keywords: Spinal fractures/therapy; Lumbar vertebrae; Thoracic vertebrae.

\section{RESUMO}

Objetivo: O objetivo deste estudo é comparar fixação posterior curta e longa em fraturas toracolombares do tipo explosão. Métodos: Cinquenta e três pacientes foram divididos em Grupo I $(n=24)$, tratados com instrumentação curta (um nível acima e um abaixo da fratura) e Grupo II $(n=29)$, tratados com instrumentação longa (dois ou mais níveis acima e abaixo da fratura). A classificação Load Sharing foi utilizada para estratificar os casos. A avaliação do índice sagital foi realizada pelo método de Cobb. Resultados: Nos subgrupos com classificação Load Sharing $\leq 6$, o Grupo I teve perda da correção de 4,2 graus e uma falha do procedimento em 14,3\% dos casos, o Grupo II apresentou perda da correção de 5, 4 graus e falha de procedimento em 21,7\% dos casos. Nos subgrupos com classificação Load Sharing $\geq 7$, o Grupo I teve perda da correção de 11,2 graus e falha do procedimento em 70\% dos casos, o Grupo Il apresentou perda da correção de 9 graus e falha de 46,7\%. O Grupo I apresentou tendência a piores resultados, principalmente no subgrupo dos pacientes que apresentavam classificação Load Sharing $\geq 7$. Conclusão: Apesar da tendência de piores resultados no grupo de fixação curta nos casos com Load Sharing $\geq 7$, em nenhuma avaliação desta amostra houve diferença estatisticamente significante entre os grupos estudados.

Descritores: Fraturas da coluna vertebral/terapia; Vértebras lombares; Vértebras torácicas.

\section{RESUMEN}

Objetivo: El objetivo de este estudio es comparar la fijación posterior corta y larga en fracturas toracolumbares del tipo explosión. Métodos: Cincuenta y tres pacientes se dividieron en el Grupo I $(n=24)$ tratados con instrumentación corta (un nivel por encima y por debajo de la fractura) y el Grupo II $(n=29)$ tratados con instrumentación larga (dos o más niveles por encima y por debajo de la fractura). La clasificación Load Sharing se utilizó para estratificar los casos. La evaluación del índice sagital se realizó mediante el método de Cobb. Resultados: En los subgrupos de la clasificación Load Sharing $\leq 6$, el Grupo I tuvo pérdida de corrección de 4,2 grados y un fracaso del procedimiento en el 14,3\% de los casos, el Grupo II mostró pérdida de corrección de 5,4 grados y falla de procedimiento de 21,7\% de los casos. En los subgrupos de clasificación Load Sharing $\geq 7$, el Grupo I tenía pérdida de corrección de 11,2 grados y falla del procedimiento en el 70\% de los casos, el Grupo II presentó pérdida de corrección de 9 grados y falla del 46,7\%. El Grupo I presentó tendencia a peores resultados, especialmente en el subgrupo de pacientes con clasificación Load Sharing $\geq 7$. Conclusiones: Apesar de la tendencia de peores resultados en el grupo de fijación corta en los casos con Load Sharing $>$ 7, en ninguna evaluación de esta muestra hubo diferencia estadísticamente significativa entre los grupos estudiados

Descriptores: Fracturas de la columna vertebral/terapia; Vértebras lumbares; Vértebras torácicas. 


\section{INTRODUCTION}

As described by Denis in 1983, the main characteristic of thoracolumbar burst fractures is a fracture in the mid-spine associated with the dislocation or rotation of the posterior cortex of the vertebral body, compressing the spinal canal and affecting spinal stability. Axial trauma concentrates an increased load directly on the mid-spine, in the region of the vertebral pedicles, resulting in their pulling away and allowing the retropulsion of fragments of the posterior portion of the vertebral body in the direction of the spinal canal. ${ }^{1}$

In general, patients with burst fractures are victims of high-energy trauma, mainly caused by falls from heights and automobile accidents. Therefore, they are serious injuries, potentially unstable both mechanically and neurologically, often associated with fractures of the extremities, most often affecting young adults. ${ }^{2}$

There is no consensus in the literature around well-defined criteria to determine which treatment will result in the best functional and/ or radiographic outcome for these patients. ${ }^{3}$

Although most authors believe that surgical treatment is required for unstable burst fractures, the choice of the best surgical approach remains unclear. ${ }^{4}$ The overall opinion is that the most stable fixation involving the smallest number of vertebrae possible should be achieved. ${ }^{5}$

Traditionally, fusions of from two to three levels above and below the fracture site are performed, although this preference could have been inherited from the first series in which several levels of fixation with wires and hooks were used to stabilize the spine and promote fusion. ${ }^{6,7}$ Pedicle screws offer significant advantages when compared to other forms of spine fixation. ${ }^{8}$

Fixation of a short segment, involving only one level above and one level below the affected vertebra, cutting back on the levels of arthrodesis, is one alternative. Biomechanical data and clinical results for short versus long fixation of the thoracolumbar spine in the treatment of these fractures still are not completely clarified. ${ }^{9}$

The objective of this retrospective study is to compare the results of short and long posterior approach fixation in thoracolumbar burst fractures.

\section{METHOD}

The study was approved by the Institutional Review Board as number CAEE: 05125612.7.0000.5479.

All participants signed the Informed Consent Form.

We evaluated radiographs in anterior and lateral views of the thoracolumbar spine of patients diagnosed with thoracolumbar (T11-L2) burst fractures, according to the criteria of Denis, ${ }^{1}$ who were treated in the Department of Orthopedics and Traumatology of the Santa Casa de Misericórdia de São Paulo from January, 2000 to January, 2011. We selected 68 patients who underwent surgical treatment for fractures at a single level.

We only included patients who underwent arthrodesis by posterior approach, with instrumentation with pedicle screws, who had complete medical records with radiographs and tomographs in good condition. The minimum follow-up time required was six months, with a radiograph in the last follow-up.

We excluded cases in which pathological fractures or fractures from firearms were suspected.

We obtained 53 patients, who were divided into two groups according to the number of instrumented levels. Group I $(n=24)$ included patients treated with short instrumentation (one level above and one level below the fracture) and Group II $(n=29)$ included patients treated with long instrumentation (two or more levels above and below the fracture).

We collected age, sex, fracture location, trauma mechanism, and follow-up time data. The neurological deficit was evaluated using the Frankel scale.

The load sharing classification was also used to stratify the cases. We scored the severity of the lesion of the vertebral body fractures considering the distance between the fragments of the vertebral body, the degree of correction of the kyphosis following posterior approach surgery, and the collapse of the vertebral body in the sagittal plane, according to McCormack et al. ${ }^{10}$

Preoperative computed tomography was used in the classification of the fracture, as described by Denis ${ }^{1}$ and McCormack. ${ }^{10}$

The radiographic evaluation was performed using the sagittal index, obtained using the Cobb method.

The clinical and radiographic data were loaded into a Microsoft Excel table and a comparative analysis of short and long fixation was performed using parametric (Student's t-test) and non-parametric (Chi square, Fisher test) methods, as appropriate. The statistical analysis was conducted using Epi Info 3.4.1 software. A value of $\mathrm{P}<0.05$ was considered significant.

\section{RESULTS}

The groups were similar in relation to sex and age, however, the long fixation group had a longer follow-up time. Falls from a height were the main trauma mechanism found in the two groups. The most common fracture level in the short fixation group was $L 2$ and in the long fixation group was L1. (Table 1)

When we stratified the groups by load sharing, we noted that among the patients who underwent short fixation $58 \%$ had a load sharing score $\leq 6$, while $52 \%$ of the long fixation group had a load sharing score $\geq 7$. (Table 2)

The sagittal index results show an average correction in regional kyphosis of 9.85 degrees in the short fixation group and 10.32 in the long fixation group. Upon comparing the radiographs of the final follow-up with those of the immediate post-operative period, we observed a loss of kyphosis of 7.13 degrees in the short fixation group and 7.55 degrees in the long fixation group. Using the procedure failure criteria: Ioss of 10 degrees in the sagittal index in the immediate postoperative period and breakage or loosening of the synthesis material, ${ }^{11}$ we observed procedure failures in nine patients in the short fixation group and 10 patients in the long fixation group. There was no statistically significant difference in any of the parameters. (Table 3 )

Analyzing the subgroup of patients with load sharing $\leq 6$, we confirmed a correction of 7.78 degrees of the kyphosis in the short fixation group and of 6.14 degrees in the long fixation group. In our evaluation of the radiographs from the last follow-up, we observed a loss in correction of 4.21 degrees in the short fixation group and 5.4 degrees in the long fixation group. A failure in the procedure was seen in $14.3 \%$ of the patients in the short fixation group and $21.4 \%$ of the patients in the long fixation group. There was no statistically significant difference between these evaluations. (Table 4)

When we selected only the cases with load sharing $\geq 7$, we observed a correction of 12.8 degrees in the sagittal index in the short

Table 1. Distribution of the patients by type of fixation.

\begin{tabular}{c|c|c|c}
\hline & Short fixation & Long fixation & $\boldsymbol{p}$ \\
\hline $\mathbf{N}$ & $\mathbf{2 4}$ & $\mathbf{2 9}$ & \\
\hline Male n (\%) & $16(66.7 \%)$ & $20(68.9 \%)$ & $0.534^{*}$ \\
\hline $\begin{array}{c}\text { Average age (min - max) } \\
\text { Average follow-up } \\
\text { time(min - max) }\end{array}$ & $24(6.2(18-63)$ & $37(21-67)$ & $0.768^{* *}$ \\
\hline Falls from heights $\mathrm{n}(\%)$ & $16(66.7 \%)$ & $55(6-108)$ & $0.007^{*}$ \\
\hline Level of Fracture & $\mathrm{L} 2 \mathrm{n}=10(41 \%)$ & $\begin{array}{c}\mathrm{L} 1 \mathrm{n}=16 \\
(55.2 \%)\end{array}$ & \\
\hline
\end{tabular}

*Student's t-test; ** Chi Square

Table 2. Load sharing score and type of fixation.

\begin{tabular}{c|c|c}
\hline & Short Fixation & Long Fixation \\
\hline Load sharing $\leq 6$ & $14(58 \%)$ & $14(48 \%)$ \\
\hline Load sharing $\geq 7$ & $10(42 \%)$ & $15(52 \%)$ \\
\hline Total & $24(100 \%)$ & $29(100 \%)$ \\
\hline
\end{tabular}


fixation group and 14.33 degrees in the long fixation group. There was a loss of correction of 11.2 degrees in the short fixation group and 9 degrees in the long fixation group. A failure in the procedure occurred in $70 \%$ of the cases in the short fixation group and in $46.7 \%$ of the cases in the long fixation group. Despite the tendency towards worse outcomes in the short fixation group, there was no statistically significant difference in any of the evaluations. (Table 5)

Most patients had no neurological deficits. Three patients in the short fixation group had partial neurological deficit, two of whom were classified as Frankel D and the other as Frankel C. There was an improvement of one Frankel scale grade in two of these patients.

In the long fixation group, six patients presented partial neurological deficit, three of whom were classified as Frankel D and three as Frankel E. There was an improvement of two Frankel scale grades in two of these patients and of one grade in three of these patients.

Table 3. Relationship between kyphosis and type of fixation.

\begin{tabular}{c|c|c|c}
\hline & Short fixation & Long fixation & $\boldsymbol{p}$ \\
\hline Pre-op Kyphosis (average) & 12.330 & 15.900 & $0.68{ }^{*}$ \\
\hline Post-op Kyphosis average) & 2.450 & 5.580 & $0.312^{*}$ \\
\hline Final Kyphosis (average) & 9.580 & 13.130 & $0.487{ }^{*}$ \\
\hline Correction (Pre-op - Post-op) & 850 & 10.320 & $0.74{ }^{*}$ \\
\hline Loss (Final - Post-op) & 7.130 & 7.550 & $0.786^{*}$ \\
\hline Failure & $9(37.5 \%)$ & $10(34.5 \%)$ & $0.412^{* *}$ \\
\hline${ }^{*}$ Student's t-test; ${ }^{*}$ Chi Square & \multicolumn{3}{|l}{}
\end{tabular}

Table 4. Relationship between synthesis failure and type of fixation.

\begin{tabular}{c|c|c|c}
\hline & $\begin{array}{c}\text { Short fixation } \\
(\mathbf{n = 1 4 )}\end{array}$ & $\begin{array}{c}\text { Long fixation } \\
(\mathbf{n = 1 4 )}\end{array}$ & $\boldsymbol{p}$ \\
\hline Correction (Pre-op - Post-op) & 7.780 & 6.140 & $0.331^{*}$ \\
\hline Loss (Final - Post-op) & 4.214 & 5.400 & $0.494^{*}$ \\
\hline Failure & $2(14.3 \%)$ & $3(21.4 \%)$ & $0.49^{*}$ \\
\hline
\end{tabular}

*Student's t-test; ${ }^{* *}$ Fisher test

Table 5. Relationship between type of fixation and loss of correction.

\begin{tabular}{c|c|c|c}
\hline & $\begin{array}{c}\text { Short fixation } \\
(\mathbf{n = 1 0 )}\end{array}$ & $\begin{array}{c}\text { Long fixation } \\
(\mathbf{n = 1 5 )}\end{array}$ & $\boldsymbol{p}$ \\
\hline Correction (Pre-op - Post-op) & 12.800 & 14.330 & $0.376^{*}$ \\
\hline Loss (Final - Post-op) & 11.200 & 9.000 & $0.365^{*}$ \\
\hline Failure & $7(70 \%)$ & $7(46.7 \%)$ & $0.144^{* *}$ \\
\hline *Student's t-test; ** Fisher test
\end{tabular}

\section{DISCUSSION}

The choice of a surgical method for the treatment of thoracolumbar burst fractures is still up for discussion. ${ }^{12}$ Several parameters, such as the type and stability of the fracture, the degree of comminution, and the presence of neurological deficit should be considered. ${ }^{13}$

McCormack et al. ${ }^{10}$ described the Load Sharing Classification to identify unstable thoracolumbar fractures that would have little capacity to support anterior load, resulting in the loss of correction and the failure of the implant. The degree of comminution of the vertebral body, the breaking away of fragments, and the degree of correction of the kyphosis should be evaluated and scored, with cases scoring greater than or equal to seven being more susceptible to anterior failure. In these cases, they recommended long posterior fixation or the association of an anterior approach and support of the vertebral body.
The anterior approach has proven to be effective, ${ }^{14}$ but it can increase the morbidity of the procedure because of longer surgical time and greater blood loss. ${ }^{15}$

In their 2011 biomechanical study involving the three spines, Lazaro et al. ${ }^{16}$ demonstrated that fixation of a short thoracic segment provided significantly less stability in vertebral injuries than a long segment fixation. With the addition of a cross-link for short fixation, there was improved stability only during axial rotation. With the addition of a screw at the site of the fracture, the stability of the short segment fixation was improved by an average of $25 \%$

In their study published in 2007, Altay et al. ${ }^{11}$ reported that, especially in young patients with load sharing equal to or less than 7 and fractures of types A31 or A32 according to the Magerl classification system, short posterior fixation can achieve adequate stability without implant failure or correction loss. In fractures with load sharing greater than 7, long fixation is more beneficial.

Tezeren and Kuru ${ }^{17}$, in their study comparing short and long segment fixation in thoracolumbar burst fractures, showed that long instrumentation is more efficient in the treatment of thoracolumbar burst fractures. Short pedicle fixation had a high failure rate. However, long fixation prolonged surgical time and significantly increased the amount of blood lost.

Our study compared patients with thoracolumbar burst fractures who underwent short and long posterior fixation. The groups were similar in terms of average age and gender distribution.

Traditionally, long fixation was more often used for thoracolumbar burst fractures. The interest in identifying fractures that would allow shorter fixation, and thus reduce the number of arthrodesis levels, is more recent. This may explain the longer follow-up time in the long fixation group, which was statistically significant.

Although several studies point to traffic accidents as being responsible for most of these fractures, ${ }^{18}$ falls from heights were the most frequent cause in our series, confirming their role as the main trauma mechanism as observed by a large number of authors who associate these fracture with serious traumas. ${ }^{19,20}$

The analysis of the sagittal index did not yield any statistically significant difference between the two groups in any of the instances evaluated. In the stratification of the groups by load sharing classification, the patients in the subgroups with a value greater than or equal to seven who underwent short fixation had a tendency towards worse results. No statistically significant difference was confirmed, but we attribute this to the limited size of the sample.

The procedure failure rate was $37.5 \%$ in the short fixation group and $34.5 \%$ in the long fixation group. As shown in Tables 4 and 5 , we can see that these cases are concentrated in the subgroups with load sharing greater than or equal to seven. This corroborates the importance of this classification in the assessment of fracture severity.

Our study is limited by its being a retrospective analysis without any randomization of the groups. The number of cases evaluated also interferes with the statistical data analysis.

\section{CONCLUSION}

The best approach method for thoracolumbar burst fractures has not yet been established. In our sample, we observed a tendency towards better radiographic results in the group that underwent long fixation as compared to the group that underwent short fixation, particularly in the subgroups with load sharing greater than or equal to seven. The Load Sharing Classification was useful in identifying the severity of the fracture and, consequently, worse results.

All the authors declare that there are no potential conflicts of interest regarding this article.

CONTRIBUTIONS OF THE AUTHORS: Each author made significant individual contributions to the development of this manuscript. RM coordinated the study and offered guidance. CAAAF, NAN, JPB, LANP, RSGU, MFSC, AO, and RM contributed to data collection and analysis, and to the critical analysis of the results. 


\section{REFERENCES}

1. Denis F. The three column spine and its significance in the classification of acute thoracolumbar spinal injuries. Spine (Phila Pa 1976). 1983;8(8):817-31.

2. Meves $R$, Avanzi O. Correlation between neurological deficit and spinal canal compromise in 198 patients with thoracolumbar and lumbar fractures. Spine (Phila Pa 1976) 2005:30(7):787-91.

3. Yi L, Jingping B, Gele J, Baoleri X, Taixiang W. Operative versus non-operative treatment for thoracolumbar burst fractures without neurological deficit. Cochrane Database Syst Rev. 2006;(4):CD005079.

4. Alanay A, Acaroglu E, Yazici M, Oznur A, Surat A. Short-segment pedicle instrumentation of thoracolumbar burst fractures: does transpedicular intracorporeal grafting prevent early failure? Spine (Phila Pa 1976). 2001;26(2):213-7.

5. Akbarnia BA, Crandall DG, Burkus K, MatthewsT. Use of long rods and a short arthrodesis for burst fractures of the thoracolumbar spine. A long-term follow-up study. J Bone Joint Surg Am. 1994;76(11):1629-35.

6. Verlaan JJ, Diekerhof $\mathrm{CH}$, Buskens E, van der Tweel I, Verbout AJ, Dhert WJ, et al. Surgical treatment of traumatic fractures of the thoracic and lumbar spine: a systematic review of the literature on techniques, complications, and outcome. Spine (Phila Pa 1976). 2004;29(7):803-14.

7. Yue JJ, Sossan A, Selgrath C, Deutsch LS, Wilkens K, Testaiuti M, et al. The treatment of unstable thoracic spine fractures with transpedicular screw instrumentation: a 3-year consecutive series. Spine (Phila Pa 1976). 2002;27(24):2782-7.

8. KimYJ, Lenke LG, Cho SK, Bridwell KH, Sides B, Blanke K. Comparative analysis of pedicle screw versus hook instrumentation in posterior spinal fusion of adolescent idiopathic scoliosis. Spine (Phila Pa 1976). 2004;29(18):2040-8.

9. Parker JW, Lane JR, Karaikovic EE, Gaines RW. Successful short-segment instrumentation and fusion for thoracolumbar spine fractures: a consecutive 41/2-year series. Spine (Phila $\mathrm{Pa}$ 1976). 2000;25(9):1157-70.
10. McCormackT, Karaikovic E, Gaines RW. The load sharing classification of spine fractures. Spine (Phila Pa 1976). 1994:19(15):1741-4.

11. Altay M, Ozkurt B, Aktekin CN, Ozturk AM, Dogan O, Tabak AY. Treatment of unstable thoracolumbar junction burst fractures with short- or long-segment posterior fixation in magerl type a fractures. Eur Spine J. 2007;16(8):1145-55.

12. Cho DY, Lee WY, Sheu PC. Treatment of thoracolumbar burst fractures with polymethyl methacrylate vertebroplasty and short-segment pedicle screw fixation. Neurosurgery. 2003:53(6):1354-60.

13. Wood KB, Bohn D, Mehbod A. Anterior versus posterior treatment of stable thoracolumbar burst fractures without neurologic deficit: a prospective, randomized study. J Spinal Disord Tech. 2005;18(Suppl):S15-23.

14. Sasso RC, Best NM, ReillyTM, McGuire RA Jr. Anterior-only stabilization of three-column thoracolumbar injuries. J Spinal Disord Tech. 2005;18(Suppl):S7-14.

15. Knop C, Bastian L, Lange U, Oeser M, Zdichavsky M, Blauth M. Complications in surgical treatment of thoracolumbar injuries. Eur Spine J. 2002:11(3):214-26.

16. Lazaro BC, Deniz FE, Brasiliense LB, Reyes PM, Sawa AG, Theodore N, et al. Biomechanics of thoracic short versus long fixation after 3-column injury. J Neurosurg Spine. $2011 ; 14(2): 226-34$

17. Tezeren $\mathrm{G}$, Kuru I. Posterior fixation of thoracolumbar burst fracture: short-segment pedicle fixation versus long-segment instrumentation. J Spinal Disord Tech. 2005;18(6):485-8.

18. McAfee PC, Yuan HA, Fredrickson BE, Lubicky JP. The value of computed tomography in thoracolumbar fractures. An analysis of one hundred consecutive cases and a new classification. J Bone Joint Surg Am. 1983:65(4):461-73.

19. Dai $L Y$, Wang $X Y$, Jiang LS, Jiang SD, Xu HZ. Plain radiography versus computed tomography scans in the diagnosis and management of thoracolumbar burst fractures. Spine (Phila Pa 1976). 2008;33(16):E548-52.

20. Meves R, Avanzi O. Correlation between neurological deficit and spinal canal compromise in 198 patients with thoracolumbar and lumbar fractures. Spine. 2006;30(7):787-91 